\title{
Conceptualization and implementation of a groundwater flow model for the Buda thermal-karst system, Hungary
}

\author{
Zahra Poyanmehr \\ Department of Physical and Applied Geology, Eötvös Loránd University, Budapest
}

\begin{abstract}
The purpose of this work was to characterize the flow system of the area by constructing a 3D steady-state model, which is able to describe the zone budget and potential levels of the flow system, and also be able to manage the different hydrostratigraphic units within different geologic zones. In this study hydrogeologic and hydraulics data of more than 100 observation and abstraction wells and springs, recorded over decades, were used and the first calibration results are presented. The VISUAL MODFLOW PRO software was applied to simulate the model.
\end{abstract}

Key words: conceptual model, digital model, karst system, thermal water, zone budget

\section{Introduction}

Budapest, the capital of Hungary, with its historically known thermal waters (ranging form 20 to $77^{\circ} \mathrm{C}$ ), plays an important role in the economy of the country. The existence of thermal water depends not only on the high geothermal gradient (1.5 times the global average), but also on the large thickness of karstic and porous aquifers. These aquifers form the hydraulically horizontally and vertically unified system connected to the cold water-bearing formations in the recharge area, which is proven by hydraulic, water geochemistry, isotopic, and geothermal data (Mádai 1927; Horusitzky 1938; Papp 1940; Kunszt 1947; Schulhof 1957; Alföldi et al. 1968, 1979, 1982; Lorberer 2002; Deák 1978). Overexploitation connected to coal mining from the 1960s to the 1980s caused a considerable drawdown in the karst system (Alföldi et al. 1980; Liebe and Székely 1980; Böcker 1981; Lorberer 1986;

Address: $\quad$ Z. Poyanmehr: H-1117 Budapest, Pázmány Péter sétány 1/c, Hungary e-mail: poyan@freemail.hu

Received: November 2, 2011; October 24, 2013 
Alföldi and Kapolyi 2007). Decrease of pressure and water levels resulted in changes in geochemical quality and quantity of thermal springs. With this background the need to study the thermal-karst system increased, in order to avoid increasing environmental threats in the future.

The current study uses the results of considerable geologic and hydrogeologic data to construct a 3D steady-state digital model of the flow system. The previous 2D or 3D models of the area (Heinemann and Szilágyi 1977; Csepregi 2007) deal with evaluating the infiltration and the effect of overexploitation connected to coal mining; to achieve these goals a one, or at times two-layered model, was sufficient. The current model deals with different hydrostratigraphic units within different geologic zones, which contributes to a better assessment of flow systems. In addition it is able to answer the appropriate questions concerning the effect of favorably or unfavorably-filled intervention; however, it is not yet able to carry out their impact assessment.

\section{Description of the study area}

The study area is located in the northeastern part of the Transdanubian Central Range (TCR). It covers the entire city of Budapest and the connected highlands and mountains - Buda, Pilis, Vác and Csővár - to the west and northwest of the capital (Fig. 1).

The main river in the area is the Danube, which separates the capital in two: the highlands of Buda on the west side of the river and the topographically flat part of the city, Pest, to the east.

The exposed Triassic-Eocene carbonate rocks located in the western and northwestern highlands are known as the main recharge area. Precipitation infiltrates through the uncovered carbonate rocks in the highlands. It flows mainly gravitationally but is also influenced by strong convective heat flow and increasing geothermal gradient $\left(75-100^{\circ} \mathrm{C} / \mathrm{km}\right.$ ) (Alföldi 1982; Lorberer 2002).

There are more than 100 springs with different temperatures and chemical compositions in Budapest, which are located along tectonic lineaments. Different temperatures, and total of dissolved solid (TDS) of thermal water, indicate the different flow paths in the area. Based on temperature and geochemical properties of thermal waters, three main discharge zones are identified in Budapest (Fig. 1) (Alföldi et al. 1968). The lukewarm springs $\left(20-28^{\circ} \mathrm{C}\right)$ from the intermediate flow system discharge in the north of Budapest (North Zone), the hot springs $\left(40-60{ }^{\circ} \mathrm{C}\right)$ from the regional flow system discharge in the south of Budapest (South Zone) and in the central zone both the lukewarm (from the intermediate flow system) and hot springs discharge next to each other (Central Zone) (Alföldi 1981; Sárváry 1995). The hot spring waters are rich in total dissolved solids $(1,200-1,700 \mathrm{mg} / \mathrm{L})$ and $\mathrm{CO}_{2}(200-400 \mathrm{mg} / \mathrm{L})$ and characterized by a Ca-Na$\mathrm{Cl}-\mathrm{SO}_{4}-\mathrm{HCO}_{3}$ hydrogeochemical facies (Goldscheider et al. 2010). 


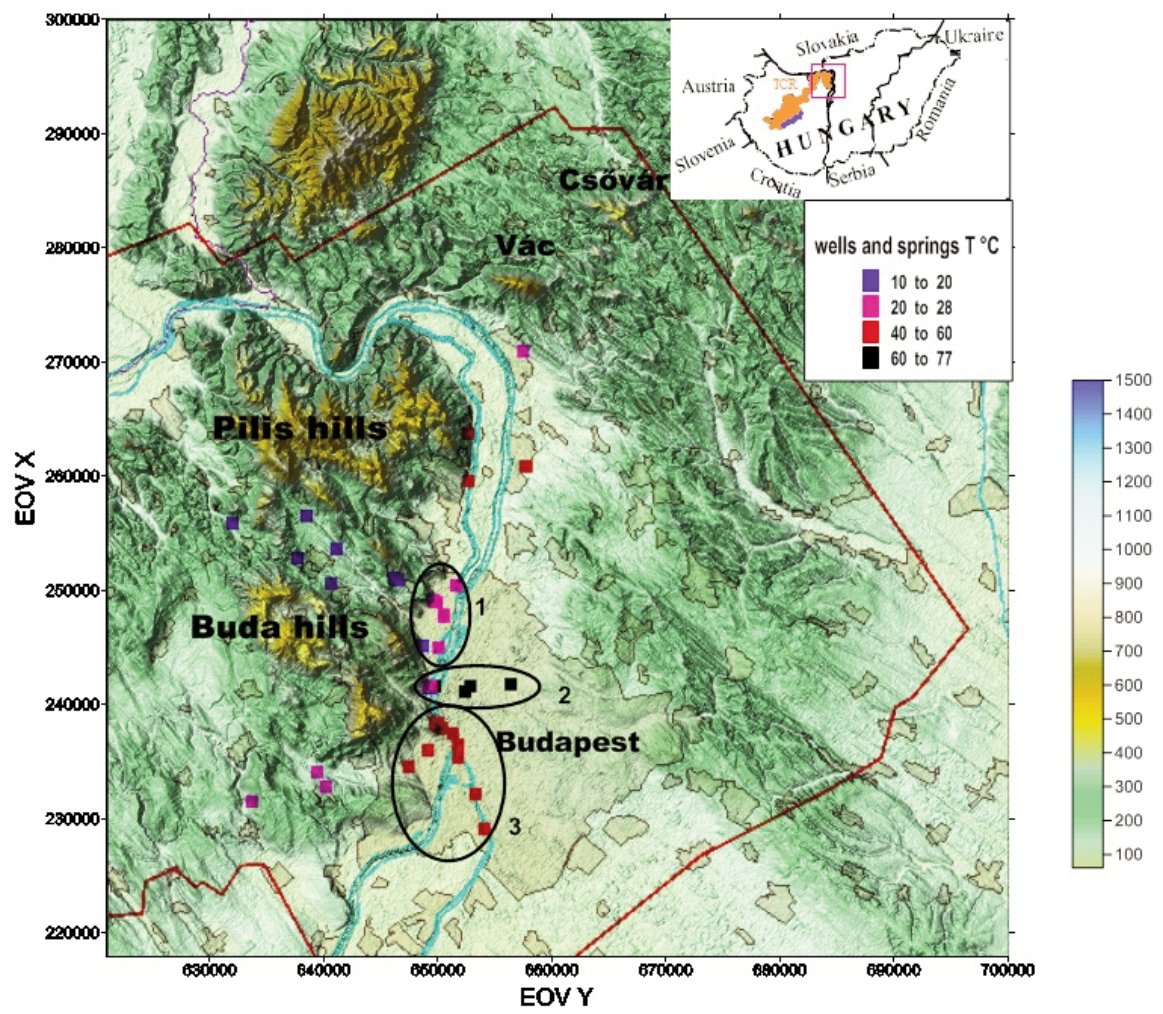

Fig. 1

Map of the study area; red line shows the active model domain; Numbers 1-3 represent the discharge zones with different temperature and geochemical properties 1 . North Zone, 2. Central Zone, 3. South Zone of Budapest; coordinates are in EOV (Hungarian National Coordinate) system; TCR: Transdanubian Central Range

\section{Geology of the study area}

The Buda thermal-karst system, as the aquifer of Transdanubian Central Range, consists of several thousand meters of Mesozoic carbonate rocks (Haas 1988), consisting mostly of dolomite and limestone (Budaörs Dolomite, Main Dolomite, Mátyáshegy Formation, Dachstein Formation) (Fig. 2). The Triassic rocks are separated from the overlying Eocene sediments by a Late Cretaceous to Eocene hiatus. From the Late Eocene to Early Miocene an approximately $700 \mathrm{~m}$ thick transgressive deposit of shallow marine limestone (Szépvölgy Limestone), pelagic marl (Buda Marl) and clay (Kiscell and Tard Clay Formations) was formed (Báldi 1983; Nagymarosy et al. 1986). Post-volcanic fluids penetrated the Triassic- 


\begin{tabular}{|l|l|l|}
\hline AGE & LITHOLOGY & \multicolumn{1}{|c|}{ FORMATION } \\
\hline QUAT. & & Clastics and travertine \\
\hline \multirow{2n}{*}{ Clastics, limestone } \\
\hline
\end{tabular}

Fig. 2

Synthetic stratigraphic chart of the Buda Hills, showing the main paleokarst and cave system horizons (1-12) (modified after Korpás 1998) 
Eocene carbonate sediments through faults during the Paleocene, which caused silicification and leaching (due to the high concentration of $\mathrm{CO}_{2}$ in fluids) along the way (Müller 1989; Nádor 1994). The gradual uplift of the area resulted in the outcropping of the Triassic-Eocene carbonate rocks during the Neogene. The uplift of these carbonate rocks led to a gravity-driven groundwater flow system at different scales, which is understood, within a conceptual framework of hierarchical flow systems, as local, intermediate, and regional flow systems (Tóth 1962, 1963, 1999).

The principal tectonic factors which led to the present-day structure are represented by the dextral W-E fault system of Late Eocene to Early Miocene age (Fodor et al. 1991, 1994). The most important role of these tectonic elements is reflected in the pre-Tertiary basement map, which was used in this study to identify the inhomogeneous zones of well-karstified sediments or the main karst layer.

\section{Hydrogeology of the study area}

The hydraulic regime of the area has been summarized by the models of Schafarzik (1928), Vendel and Kisházi (1964), Alföldi (1979, 1981) and Kovács and Müller (1980) (Fig. 3).

Based on the models of the above-mentioned authors, infiltrated water in exposed carbonate rocks in the highlands (recharge area) mainly flows downward gravitationally. Due to the high geothermal gradient of the area the difference of water temperature density are the other influencing factors for the flow system. Infiltrated water partly flows toward the Danube River (as major discharging actor) at local scale and the dominant part flows through step-fault boundaries and well-fractured carbonate rocks toward the deep part of basin, as the intermediate and regional-scale flow-paths, collecting heat on its way. Upon reaching the deepest point of the flow-path (at the base of the karstic Mesozoic sequence) on the east (Pest) side, the flow ascends through the tectonic lineaments and beneath the complex aquitard and aquiclude layers toward the springs in the western part (Buda), while on its way mixing with cold meteoric or lukewarm karstic waters of shallower and shorter intermediate flow-paths. Thus the collected heat returns to the surface at the thermal springs (Fig. 3). Due to past geologic events (subduction and rifting) and the mixing of descending meteoric water and ascending thermal waters, 12 cave horizons have developed (Fig. 2). The study of the active and inactive underwater cave system documented the mixing processes (Leél-Ôssy 1995; Leél-Ősssy and Surányi 2003; Kalinovits 2006). The karst water level in the area is 105-130 m above sea level (Lorberer and Izápy Wehovszky 1992; Jocha Edelényi and Gondár Söregi 1994), suggesting that the greatest part of the cave horizons is located below the karst water-table. 
$\mathbf{w}$

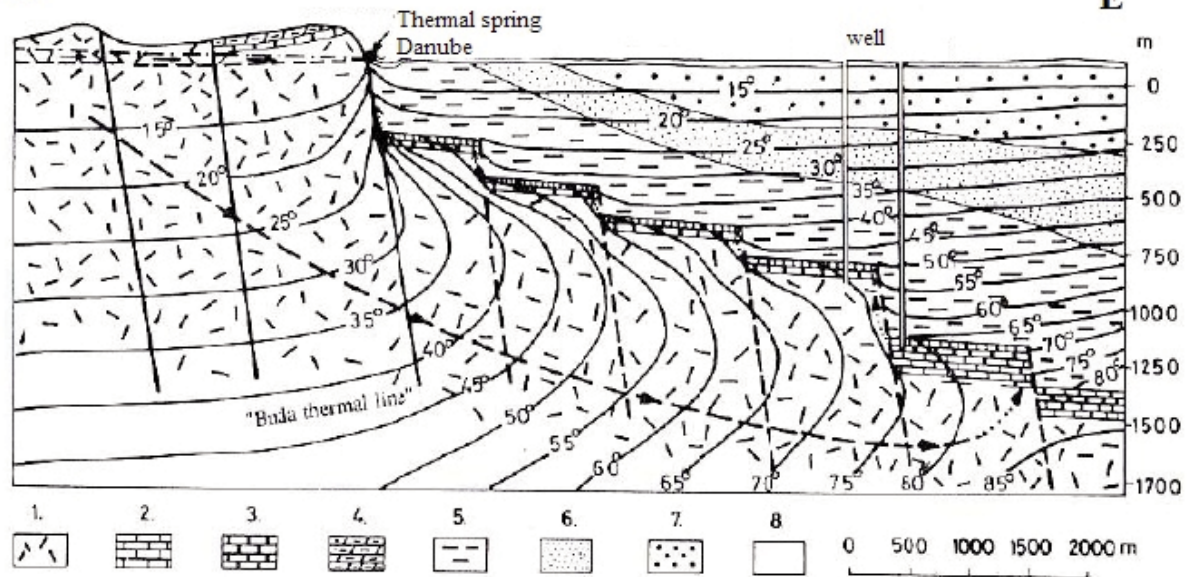

9. 10. il $60_{12}^{\circ}$

Fig. 3

Idealized scheme of the karstic water (underflow system) of Budapest (modified after Vendel and Kisházi 1964). 1. Triassic dolomite; 2. Triassic Dachstein Limestone; 3. Eocene limestone; 4. Eocene marl; 5. Middle Oligocene clay-silt; 6. Upper Oligocene sand-silt; 7. Miocene clay; 8 Pleistocene and Holocene formations; 9 . Cold shallow karstic water-flow to the springs; 10 . Karstic water underflow below the plain; 11. Ascending thermal water; 12 . Isotherm ${ }^{\circ} \mathrm{C}$

\section{Conceptual model}

The conceptual model follows the above-mentioned models of the area. It represents the role of the exposed carbonate rocks in the highlands as a main recharge area and the Danube River and the thermal springs as the main discharge mechanisms of the area. The conceptual model consists of four main hydrostratigraphic units, or model layers, with different hydrogeologic and geologic properties (Fig. 4). It deals with two aquifers (shallow unconfined and semi-confined karst aquifers). The hydrostratigraphic units or model layers are:

I. The shallow unconfined aquifer. It includes the exposed Triassic-Eocene carbonate rocks in the highlands, alluvial sediments of the river Danube and karst-covering sediment complexes on hills and hillsides.

II. The Paleogene-Neogene aquitard sediment complex, which is located between unconfined and semi-confined karst aquifers.

III. The upper $100 \mathrm{~m}$ of well-fractured and karstified carbonate sediments as the semi-confined aquifer or main karst system,

IV. Non-karstified, fresh carbonate rocks. Their base is assumed be at $-4000 \mathrm{~m}$, based on the TCR basement geologic map. 


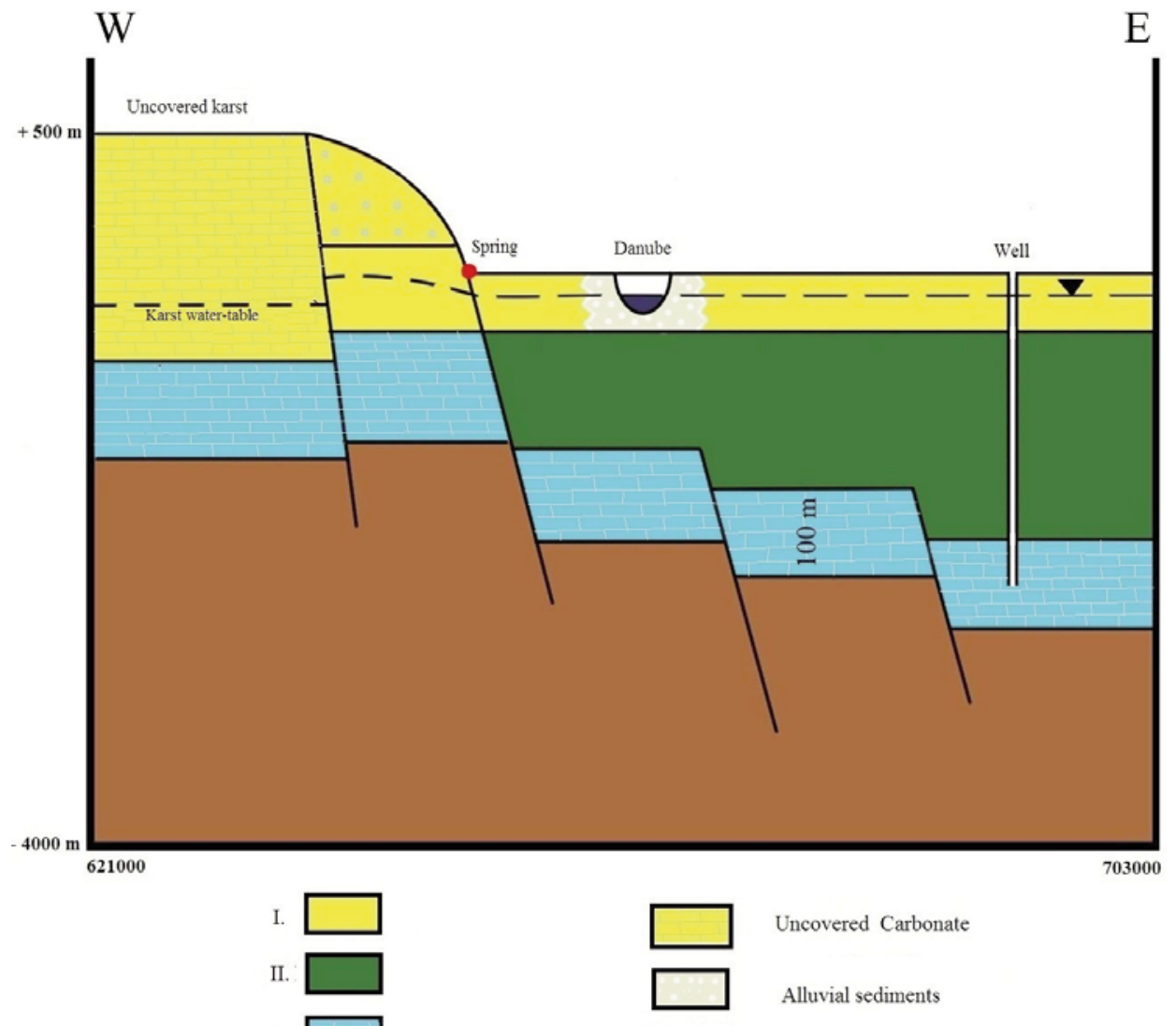

III.

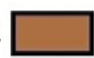

Karst-covering sediment at hills and hillsides

Fig. 4

Hydrostratigraphic units of model; I. unconfined aquifer, II. Paleogene-Neogene aquitard complex sediments, III. Semi-confined aquifer or main karst layer, IV. Non-karstified carbonate rocks

\section{Description of the model extents}

The study area is the northeastern part of the Transdanubian Central Range (TCR), located within the following limits using the EOV (Hungarian National Coordinate) system (Fig. 1):

$$
\text { EOV Y }=621 \text { 000-703 000, EOV X= } 218 \text { 000-302 } 000
$$

where the edge of the TCR was applied as the boundary of the main karst system to the NW, SW and SE, as a no-flow boundary. The NE, S and W boundaries of the model were arbitrarily applied, based on field experience, also as no-flow ones. 
The vertical extents of the model, based on the carbonate basement map of the area, were set between +500 and $-4000 \mathrm{~m}$ (i.e. between $500 \mathrm{~m}$ above mean sea level and $4000 \mathrm{~m}$ below mean sea level). The model has uniformly-sized grid cells of 400 by $400 \mathrm{~m}$, in a total of 188 rows and 190 columns.

\section{Geometry of the model}

The flow system of the area was simplified as two aquifer systems: an unconfined aquifer on the top of the model, a semi-confined aquifer as the third model layer, and with a Paleogene-Neogene complex aquitard layer located between them.

To construct the top of the first model layer the 1:50 000 scale topographic map of the area was applied. The base of this first layer was assumed to be parallel with the groundwater table. It is assumed that the groundwater-bearing layer is thin, with the same transmissibility in every part of the extent of the model. To compute the groundwater-table map (or construct the bottom of first model layer) a preliminarily one-layered and homogeneous model was run. The computed regional groundwater-table map was applied as the base of the first layer. This resulted in a very thin layer at the top of the model, the base of which is parallel with the groundwater-table surface (Fig. 5). Based on field experience, the karst water-table in the unconfined karst region is lower than the groundwater-table in the neighboring unconfined aquifers (Fig. 4). To take this issue into account the base of the first layer in the exposed carbonate region was applied below the karst water-table.

To construct the top of the main karst aquifer or third hydrostratigraphic layer, the 1: 200 000-scale map of the carbonate basement rocks of the TCR (Lorberer 2001) was applied. The thickness of this layer was assumed to be 100 meters. The base of lowest hydrostratigraphic layer (or fresh carbonate series) is relatively unknown but based on the geologic data was assumed to be at $-4000 \mathrm{~m}$.

The result of running the model showed that the configuration of the watertable (Fig. 12) is sensitive to the horizontal hydraulic conductivity of the second hydrostratigraphic model layer (Paleogene-Neogene complex layer). Therefore it was split into three homogeneous and anisotropic layers for a better configuration of the water-table (Fig. 6). This also led to a better separation of the local and regional-scale of flow systems.

Fig. $5 \rightarrow$

Four-layered model. 1. water-table bearing layer; 2. Paleogene-Neogene complex layer; 3 . main karst layer; 4. non-karstified, fresh carbonate rocks; 5 . uncovered carbonate (main recharge area); 6. inactive model extent

Fig. $6 \rightarrow$

Six-layered model; The Paleogene-Neogene complex model-layer was split into three homogeneous and anisotropic layers as 2nd, 3rd and 4th model layers 


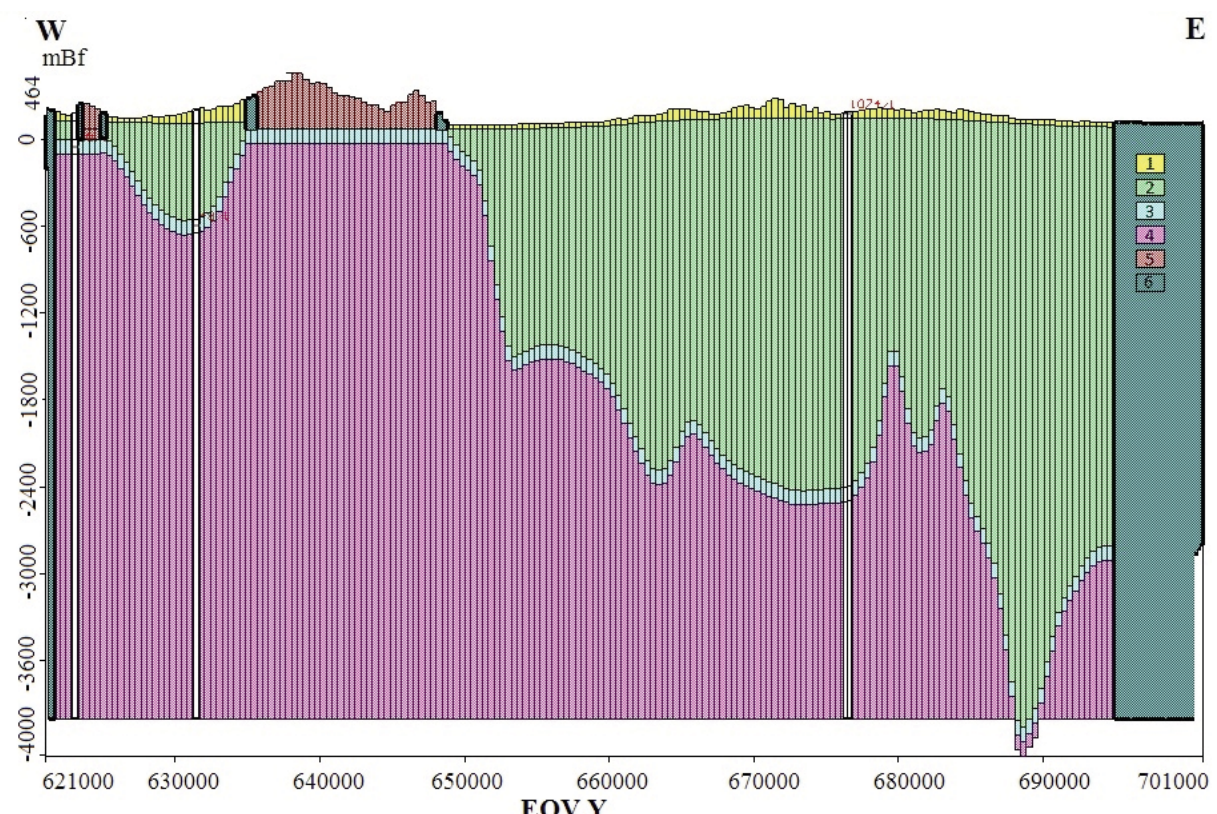

Fig. 5

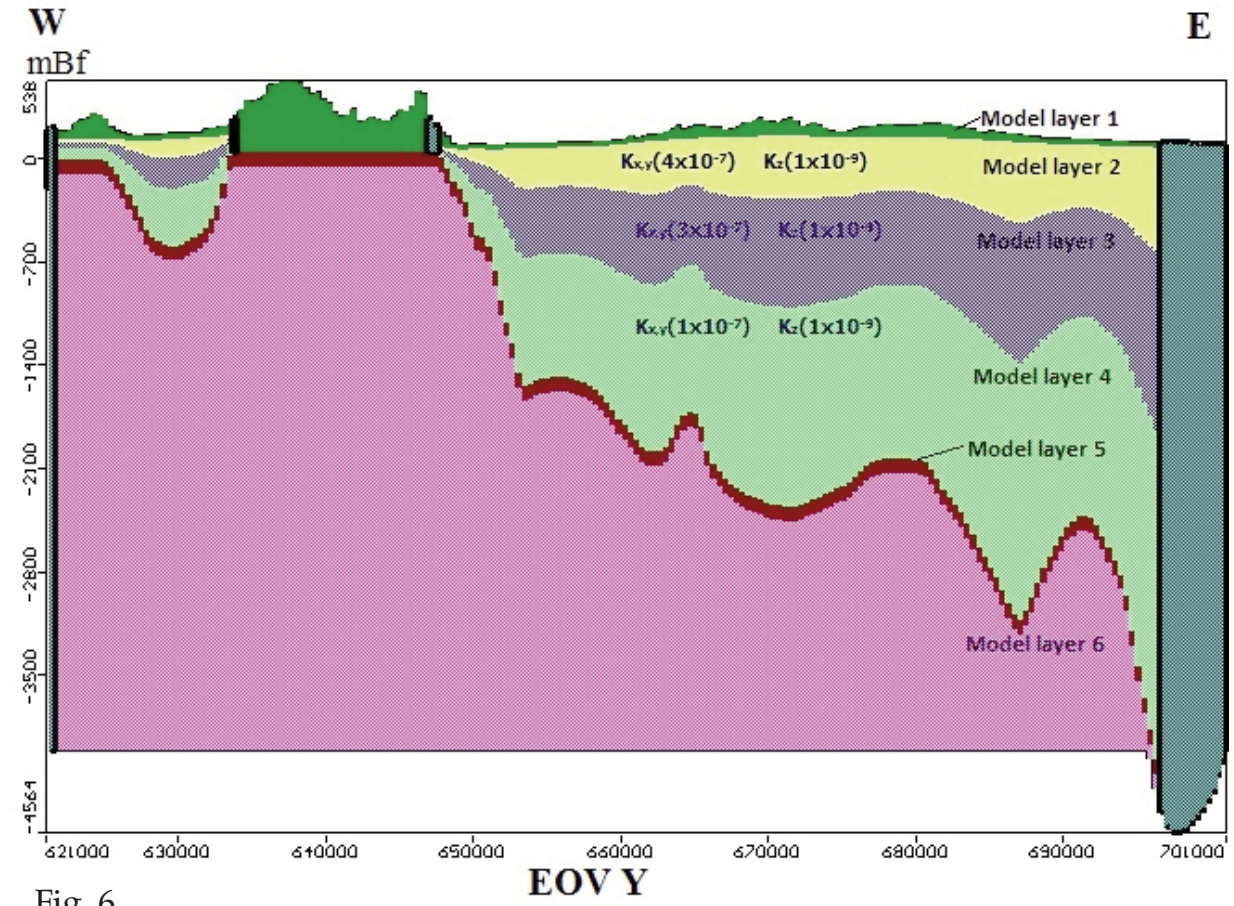

Fig. 6 
Differences of elevation between the karst water-table in the exposed carbonate region and the groundwater-table in the neighboring covering sediments (Fig. 4) caused problems for the modeling. To resolve these issues the exposed carbonate regions in the first layer were surrounded by inactive flow cells (Fig. 7).

\section{Model boundaries and initial conditions}

The active flow model domain was bordered by a no-flow boundary. The bottom of the model is the boundary between the Triassic carbonate and the aquitard-aquiclude Permian sediments, which was also represented as a no-flow boundary. Four springs were represented as the constant head boundary (Fig. 12) that simulates outflow or discharge of the main karst system. Finally, to simulate the discharging effects of the permanent springs and creeks of the deeper valleys and Danube River, the entire area of the first model layer was used as a drain or seepage surface.

The initial condition of the model is of karst water-levels in the area prior to overexploitation connected to coal mining. Thus the karst water-level map of the years before 1950 (Csepregi 2007), showing the original state of karst water levels, was applied as the initial head condition.

\section{Recharge}

The exposed carbonate areas and the surrounding thin cover layers are known as a main recharge area. To define the main recharge area, the sediments above $-100 \mathrm{~m}$ (100 m below mean sea level) around the uncovered carbonate areas were separated as a main recharge area, bordered by inactive cells (Fig. 7), to underscore the difference between water-table and karst water-table surfaces in the exposed carbonate area. Infiltration in other parts of the area was applied according to the different geologic infiltration zones. The geologic zones were defined based on the geologic polygons of the 1:100 000-scale surface geologic map published by the Geological Institute of Hungary. Estimates of recharge rates were carried out by "trial and error"-type calibration processes to support the appropriate amount of thermal water discharge. The estimated recharge of 5-60 $\mathrm{mm} /$ year resulted in $68000 \mathrm{~m}^{3} / \mathrm{d}$ discharge from the main karst layer. This amount is close to the discharge of the original state of thermal water of temperatures higher than $15{ }^{\circ} \mathrm{C}$ as reported by Gölz (1982), which was 67000 m³/d.

\section{Hydraulic properties}

Hydraulic properties were used for all model layers, including horizontal and vertical hydraulic conductivity. The estimating was done zone by zone during the "trial and error"-type calibration processes. The zones of the first model layer were separated according to the 1:100 000-scale surface geologic map (Fig. 8). To 
calibrate the estimated hydraulic properties (Table 1) the calculated water-table map was compared with the permanent stream map of the area (Fig. 11). The goal of the calibration was to show the effect of modifying stream shape on the calculated water levels.

The zones of the main karst layer were identified using the 1:100 000-scale preTertiary geologic map (published by Geological Institute of Hungary) (Fig. 9) to obtain the appropriate karst water-levels (Table 2). The thick Paleogene-Neogene hydrostratigraphic series is represented by three homogeneous and anisotropic layers (Fig. 6), the vertical hydraulic conductivity of which is several times smaller than the main karst layer $\left(\mathrm{K}_{\mathrm{z}}=1 \times 10^{-9}\right)$. The lowest model-layer is homogeneous and isotropic.

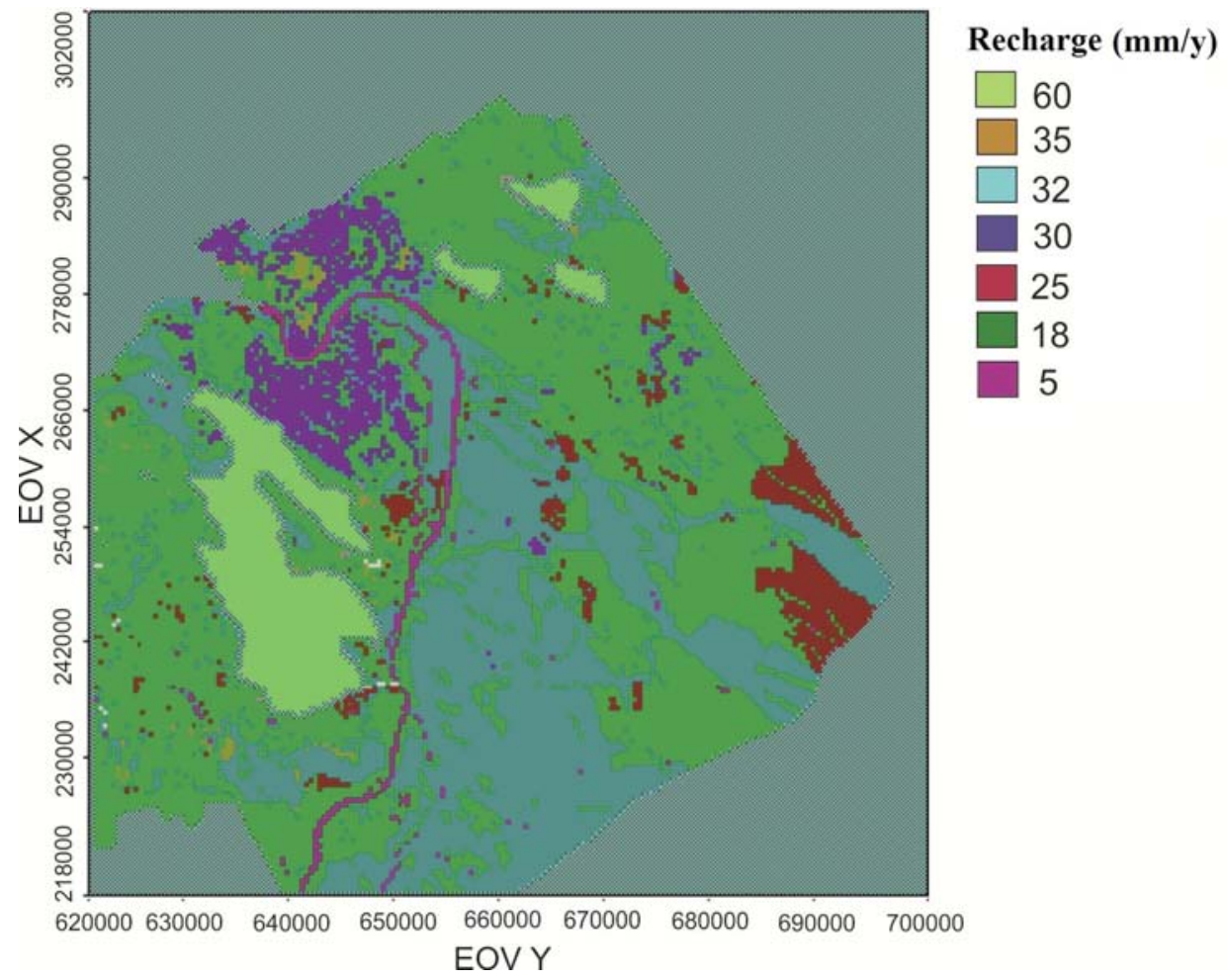

Fig. 7

Recharge map; recharge zones were delimited based on the 1:100 000-scale surface geologic map published by the Geological Institute of Hungary; exposed carbonate regions with highest recharge rate $(60 \mathrm{~mm} /$ year $)$ were bordered by inactive cells 

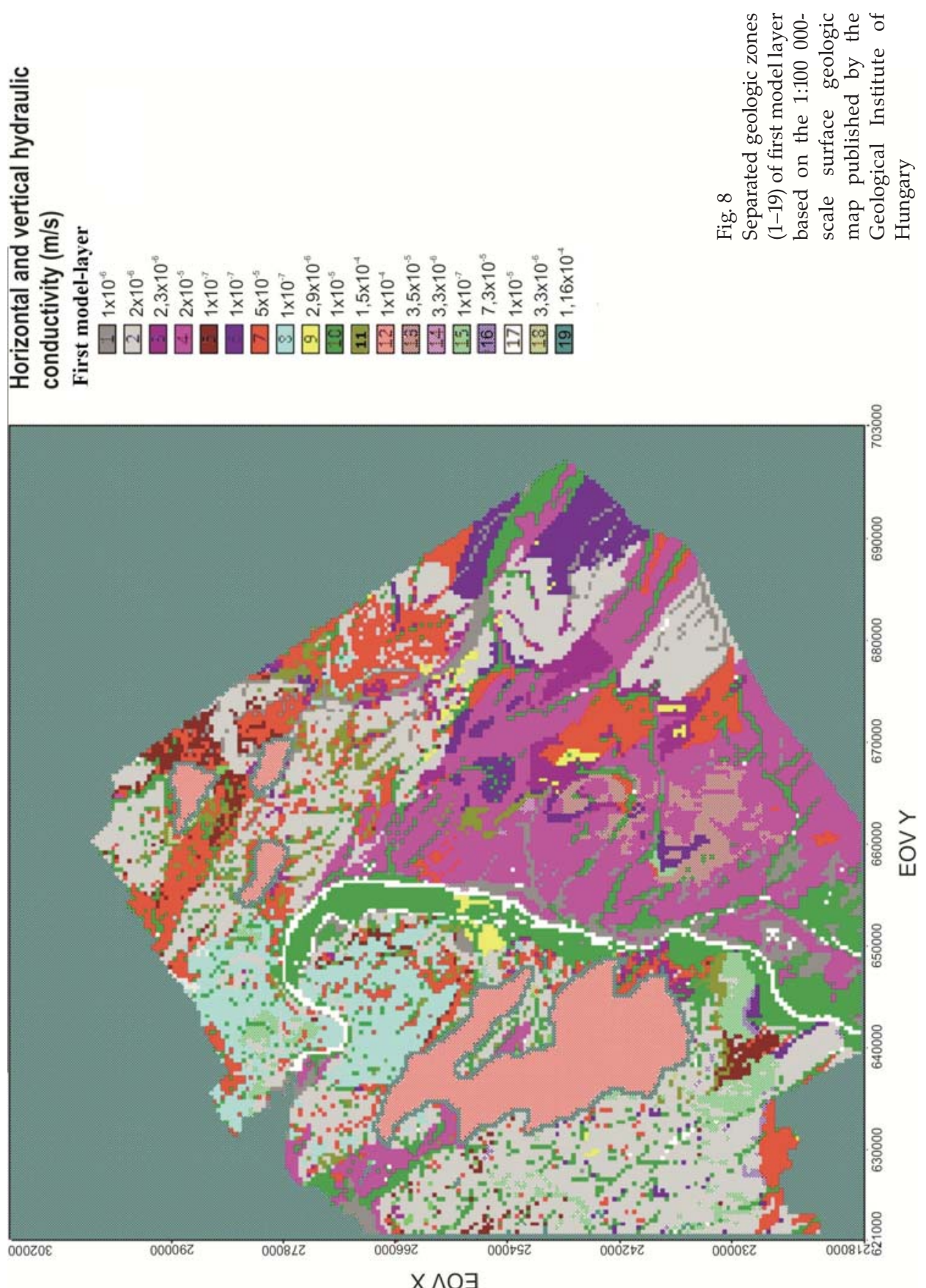
Table 1

Hydraulic conductivities of the separated geologic zones of the first model layer

\begin{tabular}{|l|l|l|}
\hline zones & \multicolumn{1}{|c|}{ Formations } & \multicolumn{1}{|c|}{$\begin{array}{c}\boldsymbol{K}_{x, y, z} \\
m s\end{array}$} \\
\hline 1 & Fluvial silt and clay & $1 \times 10^{-6}$ \\
\hline 2 & Eolian loess & $2 \times 10^{-6}$ \\
\hline 3 & Mottled clay; Nagyalföldi Tarkaagyag F. & $2.3 \times 10^{-6}$ \\
\hline 4 & Fluvial-aeolian sands & $2 \times 10^{-6}$ \\
\hline 5 & Littoral-sublittoral sand; Budafoki F. & $1 \times 10^{-7}$ \\
\hline 6 & Hydraulic clay loess & $1 \times 10^{-7}$ \\
\hline 7 & Loess & $5 \times 10^{-5}$ \\
\hline 8 & Dobogókố Andesite F.; pyroclastic andesite. & $1 \times 10^{-7}$ \\
\hline 9 & Fluvial clay. & $2.9 \times 10^{-6}$ \\
\hline 10 & Fluvial sand & $1 \times 10^{-5}$ \\
\hline 11 & Törökbálinti sandstone F.; rough-fine sandstone & $1.5 \times 10^{-4}$ \\
\hline 12 & Uncovered carbonate and area above 100 m B.s.l & $1 \times 10^{-4}$ \\
\hline 13 & Fluvial sediments & $3.5 \times 10^{-5}$ \\
\hline 14 & Tari Dacite-Tuff F. & $3.1 \times 10^{-6}$ \\
\hline 15 & Tinnyei F., brackish coastal limestone, limestone & $3 \times 10^{-7}$ \\
\hline 16 & Zámori gravel F. & $7.3 \times 10^{-5}$ \\
\hline 17 & Fluvial sediments & $1 \times 10^{-5}$ \\
\hline 18 & $\begin{array}{l}\text { Hárshegyi sandstone F., littoral-sublittoral rough } \\
\text { sandstone }\end{array}$ & $3.3 \times 10^{-6}$ \\
\hline 19 & Fluvial silt and clay & $1.16 \times 10^{-4}$ \\
\hline & & \\
\hline
\end{tabular}

\section{Zone budget}

To compute the zone budget of the study area, it was vertically split into four layers (water-table bearing layer, Paleogene-Neogene layer, main karst layer and fresh carbonate layer) (Fig. 9).

The results of water balance, or the water budget, of the area is $283677 \mathrm{~m}^{3} /$ day total inflow in the entire study area; $76 \%$ of the total infiltrated water drains from the first layer of the model to the surface as a local system, and the other $24 \%$ discharges from the regional main karst layer through the thermal springs or wells. The computed value of $24 \%$ is about $68000 \mathrm{~m}^{3} /$ day, which is close to the total discharge of wells and springs with a temperature above $15{ }^{\circ} \mathrm{C}$ (67 $000 \mathrm{~m}^{3} /$ day) reported by Gölz (1982). 
Table 2

Hydraulic conductivities of the separated geologic zones of main karst layer

\begin{tabular}{|c|c|c|c|}
\hline zones & Formations & $\begin{array}{l}\boldsymbol{K}_{x, y} \\
m s\end{array}$ & $\begin{array}{l}\boldsymbol{K}_{z} \\
m \xi\end{array}$ \\
\hline 1 & $\begin{array}{l}\text { Upper Permian shallow marine } \\
\text { carbonate-evaporate deposits }\end{array}$ & $3 \times 10^{-4}$ & $1 \times 10^{-6}$ \\
\hline 2 & $\begin{array}{l}\text { Lower Triassic shallow marine } \\
\text { siliciclastic-carbonate deposits }\end{array}$ & $2 \times 10^{-4}$ & $1 \times 10^{-6}$ \\
\hline 3 & $\begin{array}{l}\text { Upper Triassic, Lower Jurassic } \\
\text { platform limestone }\end{array}$ & $1 \times 10^{-4}$ & $1 \times 10^{-6}$ \\
\hline 4 & $\begin{array}{l}\text { Ladinian-Karnian platform } \\
\text { dolomite }\end{array}$ & $1 \times 10^{-5}$ & $1 \times 10^{-6}$ \\
\hline 5 & $\begin{array}{l}\text { Karnian basinale marl and } \\
\text { limestone }\end{array}$ & $1 \times 10^{-4}$ & $1 \times 10^{-6}$ \\
\hline 6 & Karnian-Norian platform dolomite & $1 \times 10^{-4}$ & $1 \times 10^{-6}$ \\
\hline 7 & $\begin{array}{l}\text { Upper Triassic, Lower Jurassic } \\
\text { platform limestone and Norian- } \\
\text { Rhaetian basinal limestone, } \\
\text { dolomite }\end{array}$ & $3 \times 10^{-4}$ & $4 \times 10^{-6}$ \\
\hline 8 & $\begin{array}{l}\text { Upper Triassic, Lower Jurassic } \\
\text { platform limestone }\end{array}$ & $1 \times 10^{-4}$ & $1 \times 10^{-6}$ \\
\hline 9 & Middle Jurassic olistrom-melange & $1 \times 10^{-4}$ & $1 \times 10^{-6}$ \\
\hline
\end{tabular}

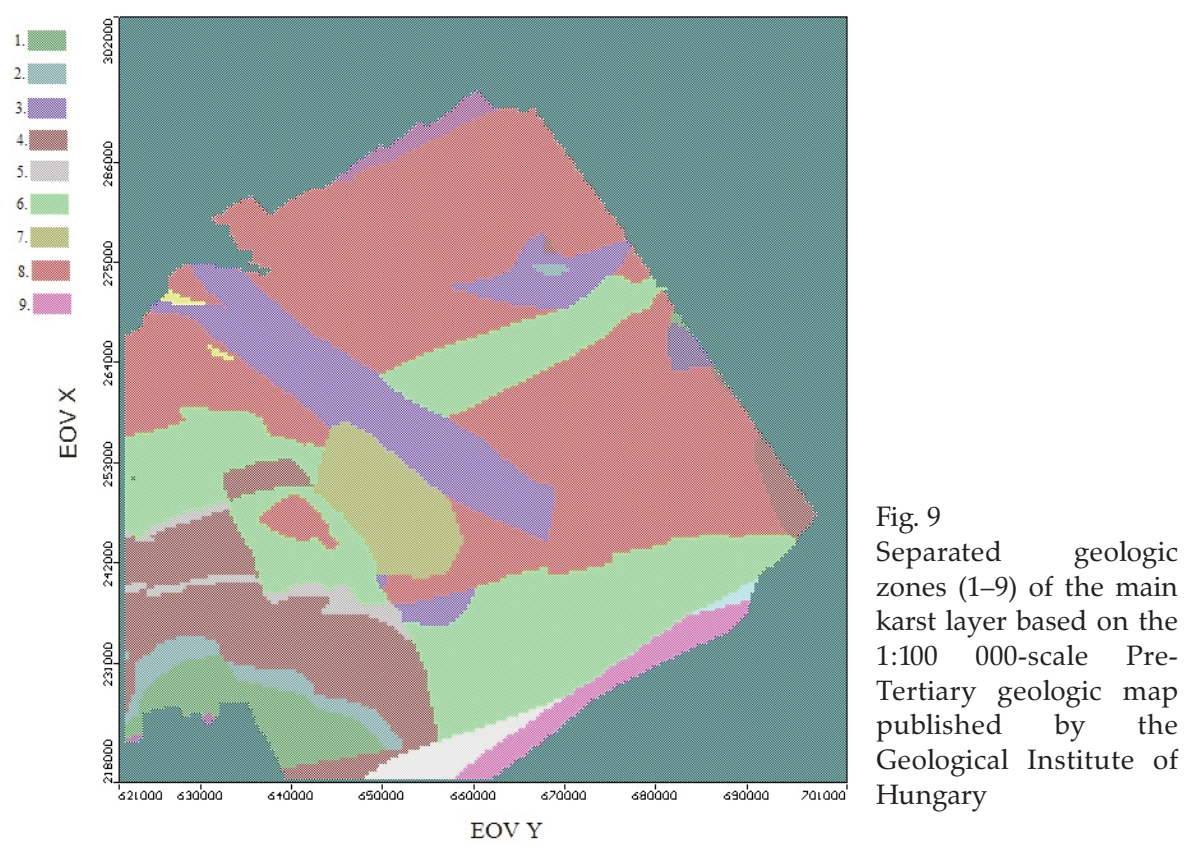


To calculate the input of the main karst layer from the thick PaleogeneNeogene complex layer located between the two aquifers, or the role of the covering layer in transporting any surface contaminant, it was split into an upper and a lower zone (Fig. 10). The boundary applied between these two zones was based on the carbonate baseman of the TCR at the $-500 \mathrm{~m}$ equipotential line; thus the Paleogene-Neogene complex layer was split into an upper zone (shallower than $-500 \mathrm{~m}$ ) and a lower one (deeper than $-500 \mathrm{~m}$ ). The assumption was that, around the recharge areas, where the karst-covering layer (Paleogene-Neogene layer) is thinner than $500 \mathrm{~m}$, the majority of the infiltrated water directly flows into the karst layer.

The computed value of the budget of the Paleogene-Neogene complex aquitard layer indicates $50 \%$ (8 $401.5 \mathrm{~m}^{3} /$ day) of inflow of the layer flow toward the karst system through the edge of the upper zone, with the other $50 \%$ (7 779.8 $\mathrm{m}^{3}$ /day) flowing toward the lower zone, despite the fact that the latter has a significant contact area with the karst layer. This fact reflects the sensitivity of the thermal-karst system to infiltrated pollution near the surface, through the

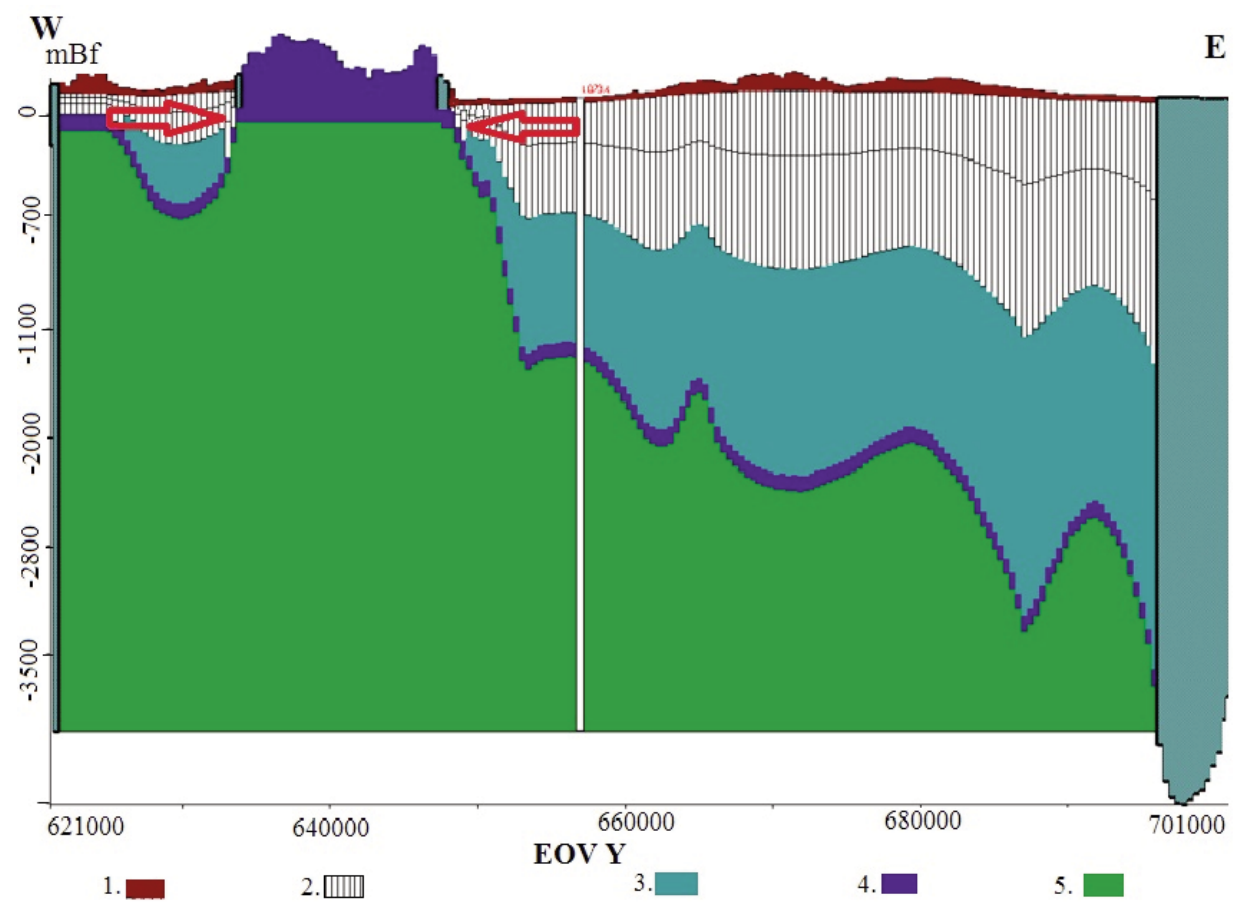

Fig. 10

Separated layers for calculating the zone budget of the model extent (W-E caption); 1 . water-table bearing layer; 2 . upper zone of the Paleogene-Neogene complex aquitard layer; 3. lower zone of the Paleogene-Neogene complex aquitard layer; 4. main karst layer; 5. non-karstified rocks. Red arrows show the contact area of the upper zone of the karst-covering layer with the main karst layer 
edge of the upper zone of the covering sediments. Thus the model simulated the possibility of transporting surface contaminant to the karst system through the edge of the upper zone of the covering sediments.

\section{Model calibration}

Calibration was carried out through trial-and-error adjustments of the heads of 24 shallow observation wells in the first layer of the model and 64 karst abstraction-observation wells in the karst layer. The calculated karst water-level in the main karst layer (Fig. 11) is $125 \mathrm{~m}$ in the uncovered carbonate area, which

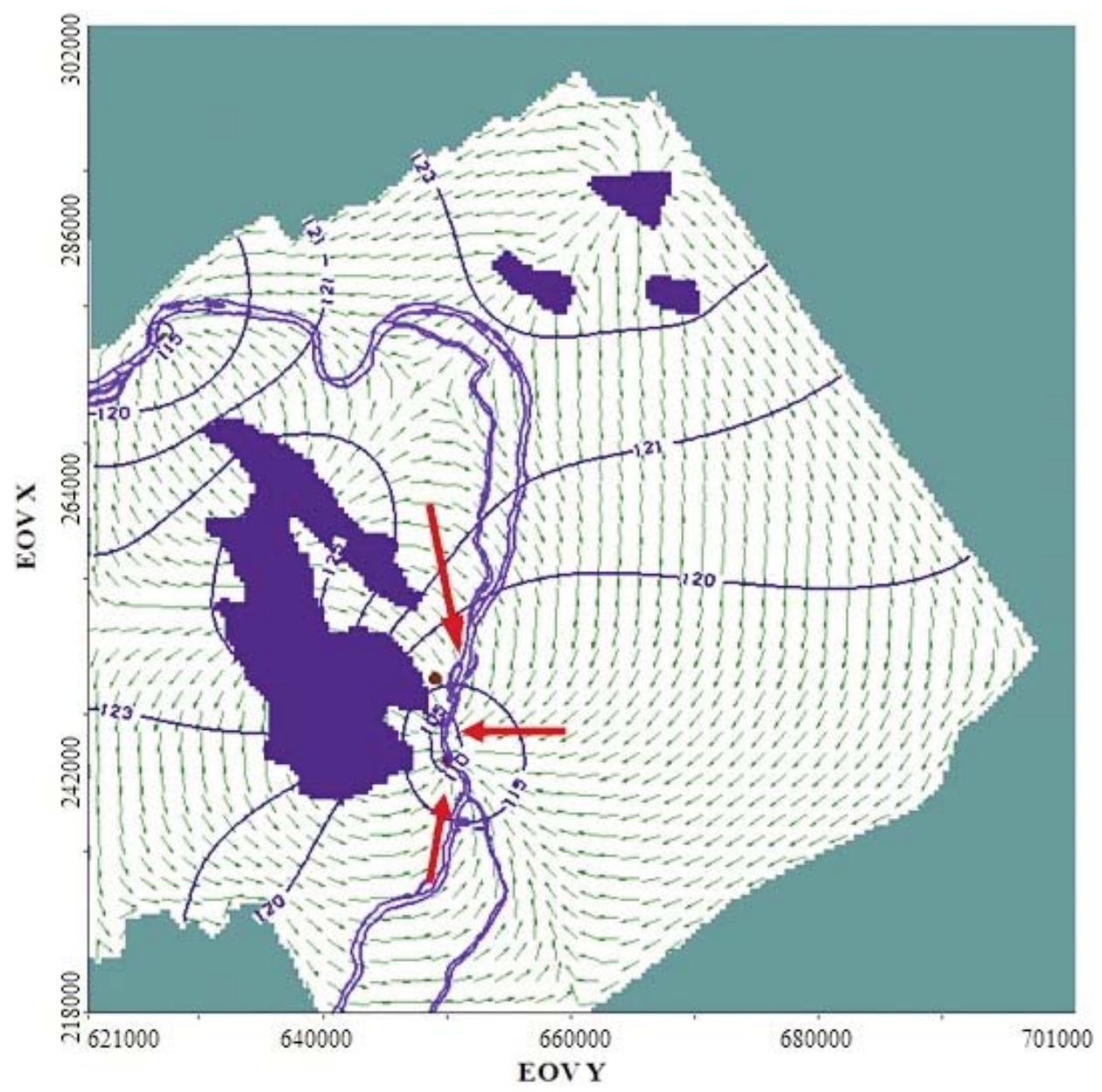

Fig. 11

Karst water-levels of the main karst layer; arrows show the main three flow paths in the Budapest area; the recharge area is shown in blue 


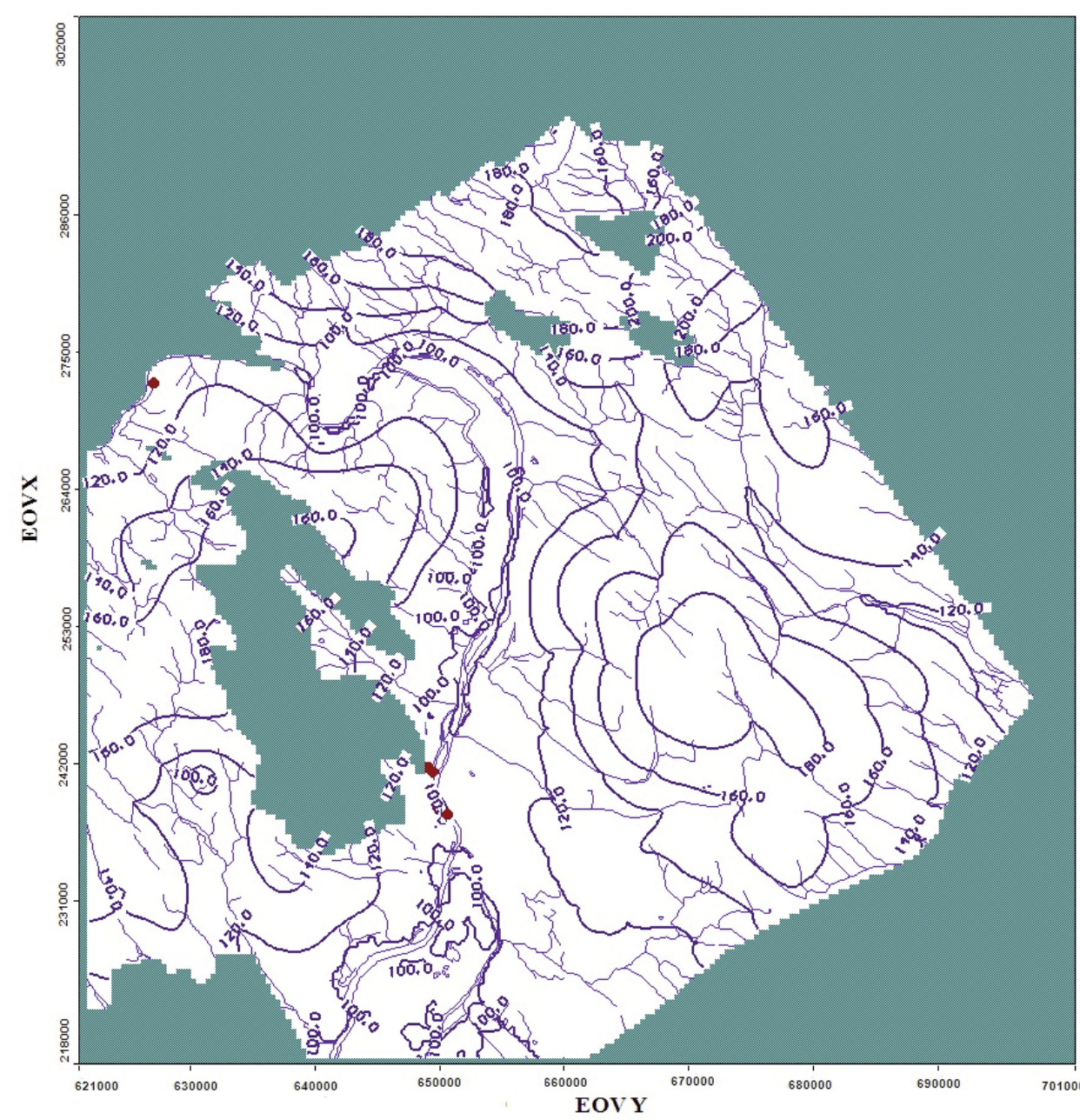

Fig. 12

Calculated water-table map of first layer of the model; $\bullet$ : spring as a constant head

confirms the published 120-125 m b.m.s.l karst water-level in the Pilis Hills and 120-130 m b.m.s.l in the Buda Hills (Lorberer and Izápy Wehovszky. 1992; Csepregi 2007). Furthermore, the green arrows showing the flow directions (Fig. 11) outline the three main flow directions in Budapest, which confirm the previously-mentioned three discharge zones (North, South and Central Zones) in Fig. 1.

In the first layer of the model, in order to calibrate the calculated water levels, the permanent surface-water map was compared to the calculated water-table map (Fig. 12) to determine the best shape-modification of permanent streams and rivers on the calculated water-table isolines. 


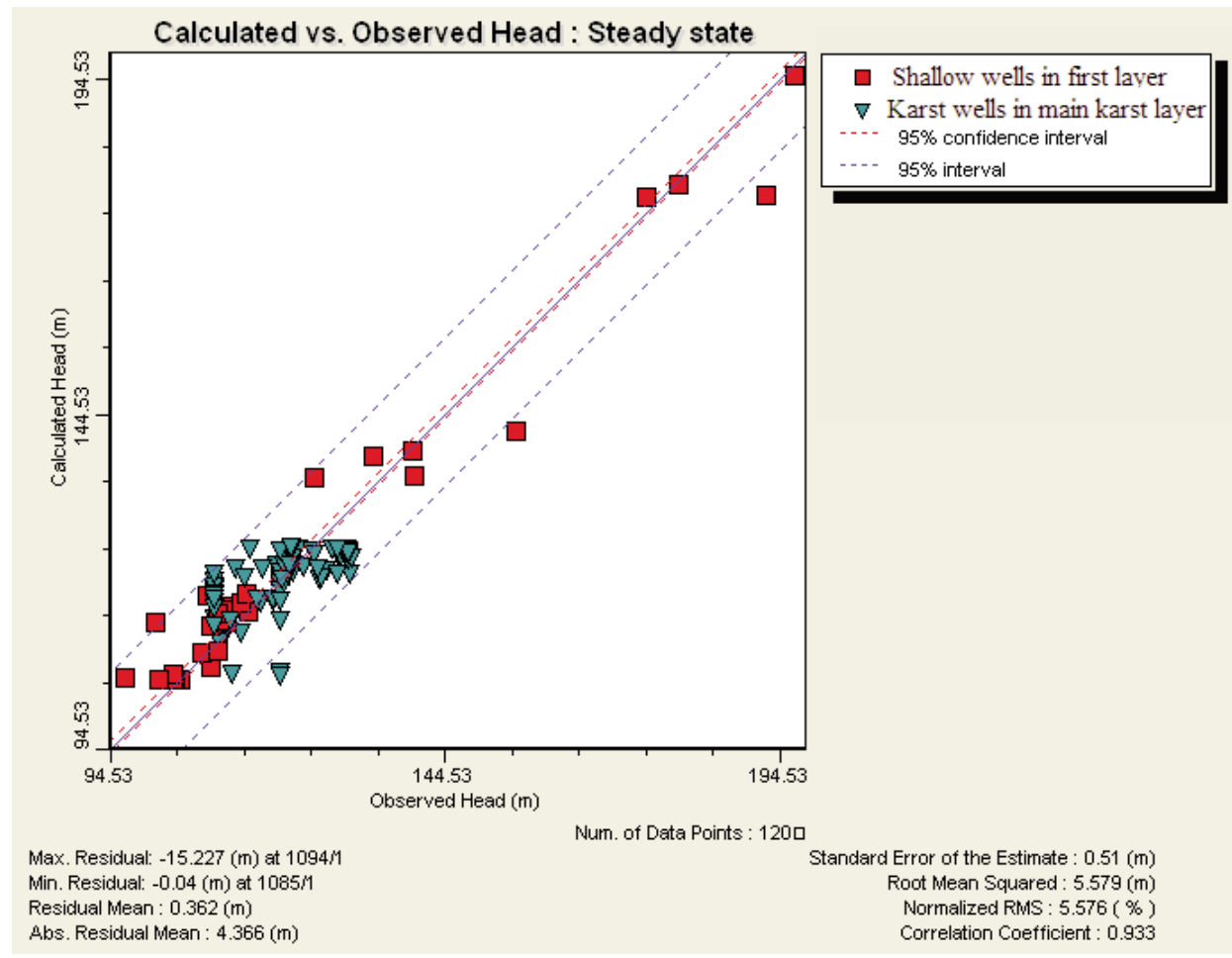

Fig. 13

Model results of calculated versus observed head

In the main karst layer the calibration result of calculated versus observed head (Fig. 13) displays a satisfactory calibration; the correlation coefficient is 0.933 . Only two shallow wells and two karst wells fall outside of the 95\% interval. The 95\% interval represents the width of the zone into which $95 \%$ of the measured values fall. The landing of four wells outside of the $95 \%$ interval is most probably related to the size of the model cells $(400 \times 400 \mathrm{~m})$ or bad data recording. The normalized root mean squared error is less than 6 (NRMS $=5,58 \%$ ), which is relatively small and an acceptable result for goodness of fit of water levels in both aquifers. This is a good basis for transient calibration in the future, to ensure the sustainability of karst water-sources and to delineate the main threatening contamination sites.

\section{Summary}

The purpose of this work was to characterize the flow system of the area by constructing a 3D steady-state model, which is able to describe the zone budget, 
potential levels of the flow systems and capable of managing the different hydrostatic layers with various geologic zones.

The flow system was simplified to two aquifer systems, the uncovered shallow aquifer and the semi-covered karst aquifer, which are separated by the Paleogene-Neogene aquitard complex layer. The model successfully characterized the recharge, discharge and zone budget conditions, as well as the main flow paths of the area. The model was calibrated by karst water and watertable levels. The results of the model are summarized as follows:

- By defining a two-aquifer system as a unique one, the local and the regional flow systems were successfully separated from each other;

- The computed karst water-table map of the main karst layer confirmed the three main flow paths in the Budapest area;

- By computing the water balance or the water budget of the area, it was determined that $76 \%$ of the total infiltrated water drains to the surface as a local system, and that $24 \%$ are discharges from the regional main karst system through the springs or wells of the thermal-karst system. The latter value $(24 \%$, or 68,000 $\mathrm{m}^{3} /$ day) confirms the published value of the discharge of thermal water with temperatures above $15^{\circ} \mathrm{C}$;

- By splitting the Paleogene-Neogene complex aquitard layer, which is located between the two aquifers, into an upper (shallower than $-500 \mathrm{~m}$ ) and a lower (deeper than $-500 \mathrm{~m}$ ) zone and computing the budget of the layer, it was determined that $50 \%$ of infiltrated water of the Paleogene-Neogene layer flows toward the karst system through the edge of the upper zone. Thus the model simulated the fact which reflects the sensitivity of the thermal-karst system to infiltrated surface contaminant through the edge of the upper zone of the covering sediments.

\section{References}

Alföldi, L., L. Béltekey, T. Böcker, J. Horváth, H. Kessler, K. Korim, J. Oravecz, G. Szalontai 1968 : Budapest hévizei (Thermal water of Budapest). - Water Resources Research Centre (VITUKI), Budapest, 365 p. (In Hungarian.)

Alföldi, L. 1979: Budapesti hévizek (Thermal waters of Budapest). - Water Resources Research Centre (VITUKI) Proceedings 20, pp. 3-102. (In Hungarian.)

Alföldi, L. 1982: A layered thermal-water twin flow system. - Hydrology Journal, 56, pp. 99-105. Alföldi L., J. Deák, P. Liebe, Á. Lorberer 1980: A középhegység hideg és meleg karsztvízkészletek összefüggése, különös tekintettel a bányászat víztelenítési törekvésére (Relations between thermal and cold karstic water resources, with special emphasis on groundwater extraction during mining activity). - Water Resources Research Centre (VITUKI), Proceedings 23. (In Hungarian.)

Alföldi, L. 1981: A budapesti geotermikus áramlási rendszer modellje (Model of the geothermal flow system in Budapest) - Hidrológiai Közlöny (Bulletin of the Hungarian Hydrological Society), 61/9, pp. 397-403. (In Hungarian.)

Alföldi, L., L. Kapolyi (editors) 2007: Bányászati karsztvízszint-süllyesztés a Dunántúliközéphegységben (Groundwater extraction and karstic water level sink connected to 
dewatering of mines in the Transdanubian Central Range). - Hungarian Academy of Science Geographical Institute, 138 p.(In Hungarian.)

Báldi, T. 1983: Magyarországi oligocén és alsó miocén formációk (Oligocene and Lower Miocene Formations in Hungary). - Akadémiai Kiadó, Publishing House of the Hungarian Academy of Science), $293 \mathrm{p}$.

Böcker, T., Á. Lorberer, L. Maucha 1981: A karsztvízszintek és a bányavízkivételek sokévi változása a Dunántúli-középhegységben (Az 1981 évi karsztvízszint-térkép hátnyomata, magyarázó szöveggel) (Long-term karstic water level changes and groundwater extraction changes in the Transdanubian Central Range-Map of the 1981 year karstic water level with explanations). Water Resources Research Centre (VITUKI) and Cartography Company, Budapest. (In Hungarian.)

Csepregi, A. 2007: A karsztvíztermelés hatása a Dunántúli-középhegység vízháztartására (Effect of karstic water extraction on the groundwater reserve of the Transdanubian Central Range). - In: Alföldi L., L. Kapolyi (Eds): Bányászati karsztvízszint-süllyesztés a Dunántúliközéphegységben, (Groundwater extraction and karstic water level sink connected to dewatering of mines in the Transdanubian Central Range). - Hungarian Academy of Science Geographical Institute, Budapest, pp. 77-112. (In Hungarian.)

Deák, J. 1978: Environmental isotopes and water chemical studies or groundwater research in Hungary. - Isotope Hydrology, IAEA-SM-228/13, Vienna, pp. 221-249.

Erőss, A., J. Mádl-Szőnyi, E.A. Csoma 2008: Characteristics of discharge at Rose and Gellért Hills, Budapest, Hungary. - Central European Geology, 51, pp. 267-281.

Erőss, A., J. Mádl-Szőnyi, A. Csoma 2012: Hypogenic karst development in a hydrogeological context, Buda Thermal Karst, Budapest, Hungary. - In: Maloszewski P., S. Witczak, G. Malina (Eds): Groundwater Quality Sustainability. IAH Selected Papers on Hydrogeology, 17, pp. 19-133.

Erőss, A., J. Mádl-Szőnyi, H. Surbeck, Á. Horváth, N. Goldscheider, A. Csoma 2012: Radionuclide as natural tracers for the characterization of fluids in regional discharge areas, Buda Thermal Karst. Hungary. - Journal of Hydrogeology, 426-427, pp. 124-137.

Fodor, L., A. Nagymarossy, A. Fogarasi, Á. Magyari, K. Palotás, I. Gatter 1991: A Buda vonal geológiai elemzése (Structural analysis of the Buda Line), Research Report). - Eötvös Lóránd University. (In Hungarian.)

Fodor, L., Á. Magyari, A. Fogarasi, K. Palotás, K. Gatter 1994: Tercier szerkezetfejlődés és késő paleogén üledékképződés a Budai-hegységben. A Budai-vonal új értelmezése (Tertiary tectonics and Late Paleogene sedimentation in the Buda Hills, Hungary, A new interpretation of the Buda line) - Földtani Közlöny, 124/2, pp. 130-305. (In Hungarian.)

Goldscheider, N., J. Mádl-Szőnyi, A. Erőss, E. Schill 2010: Review: Thermal water resources in carbonaterock aquifers. - Hydrogeology Journal, 18, pp. 1303-1318.

Gölz, B. 1982: A Dunántúli-középhegység forrásainak természetes hőteljesítménye (Heat yield of the thermal springs of the Transdanubian Central Range). - Földrajzi Értesítő 31. pp. 427-447 (In Hungarian.)

Gyalog, L., T. Budai, G. Chikán, J. Ivancsics, M. Kaiser, B. Koroknai, S. Kovács, V. Maigut, P. Pelikán, F. Sikhegyi, G. Turczi 2005: Magyarázó Magyarország fedett földtani térképéhez 1:100 000 (Commentary to Geological Map of Hungary, 1:100 000) - Hungarian Geological Institute 189. p. (In Hungarian.)

Haas, J. 1988: Upper Triassic carbonate platform evolution in the Transdanubian Mid-Mountains. Acta Geologica Hungarica, 31/3-4, pp. 299-312.

Heinemann, Z., G. Szilágyi 1977: A Dunántúli-középhegység fớkarsztvíz-rendszerének szimulációja (Simulation of the karstic water system of the Transdanubian Central Range). - Bányászati és Kohászati Lapok, 110/11. pp. 750-758. (In Hungarian.)

Horusitzky, H. 1938: Budapest Duna jobbparti részének (Budának) hidrogeológiája (Hydrogeology of Buda). - Hidrológiai Közlöny (Bulletin of the Hungarian Hydrological Society), XVIII, pp. 1-404. (In Hungarian.) 
Jocha Edelényi, E., K. Gondár Söregi 1994: A Dunántúli-középhegységi depressziók feltöltődésének geológiai meghatározottsága (Geological control in the processes of refilling of karstwaterdepression in Transdanubian Central Range). - Hungarian Geological Institute Library. 358 p. (In Hungarian.)

Kalinovits, S. 2006: Molnár János-barlang új szakaszainak felfedezése (Discovery of the new passages of Molnár János Cave). - Karszt és Barlang (Journal of the Hungarian Speleology Society) 1995-1996, pp. 3-8. (In Hungarian.)

Korpás, L. 1998: Paleokarst studies in Hungary. - Doctor of Science Thesis, submitted to Hungarian Academy of Science, 139 p. (In Hungarian.)

Kovács, J., P. Müller 1980: A Budai-hegység hévizes tevékenységének kialakulása és nyomai (Thermal water activity of Buda hills). - Karszt és Barlang (Journal of the Hungarian Speleology Society) 1980/II, pp. 93-98. (In Hungarian.)

Kunszt, J. 1947: A Rudas gyógyfürdő monográfiája (Monograph of the Rudas Spa). - Budapest Központi Gyógy- és Üdülőhely Bizottság (Central Committee of Recreation) 221 p. (In Hungarian.)

Leél-Őssy, Sz. 1995: A Rózsadomb barlangjai (The caves of the Rózsadomb). - Földtani Közlöny (Geological Journal of the Hungarian Geological Society), 125/3-4, pp. 363-432. (In Hungarian.)

Leél-Ôssy, Sz., G. Surányi 2003: Peculiar hydrothermal caves in Budapest, Hungary. - Acta Geologica Hungarica, 46/4, pp. 407-436.

Liebe, P., F. Székely 1980: Nyomáscsökkenések vizsgálata és előrejelzése hévízkutakban (Pressure drop analysis and forecast in thermal water wells). - Water Resources Research Centre (VITUKI), Report, 23 p. (In Hungarian.)

Lorberer, Á. 1986: A Dunántúli-középhegység karsztvízföldtani és vízgazdálkodási helyzetfelmérése és döntéselőkészítő értékelése (Assessment report of karst hydrogeology and water management of Transdanubian Central Range). - Water Resources Research Centre (VITUKI), Summary Report I. (TSZ.:7611/1/62), 130 p. (In Hungarian.)

Lorberer, Á. 2001: Map of karstwater level of Transdanubian Central Range, NE part/ mBf/, M= 1:200000. - Water Resources Research Centre (VITUKI).

Lorberer, Á. 2002: A budapesti termálkarszt állapot-értékelése (Assessment of Buda Thermal Karst. Water Resources Research Centre (VITUKI), Report. (In Hungarian.)

Lorberer, Á, E. Izápy Wehovszky 1992: A Dunántúli-középhegység karsztvízszint térképe (Map of karstwater-table of the Transdanubian Range) Scale: 1:200 000. - International Karsthydrology Symposium, Proceedings I., pp. 79-110. (In Hungarian.)

Lorberer, Á., P. Liebe, L. Szentirmai 1977: A budapesti hévíztermelés és a bányászati víztelenítések kapcsolatának vizsgálata (Connection of thermal water exploitation and mining activity related water level subsidence). - Water Resources Research Centre (VITUKI), Report, III. 4. 1. 22. (In Hungarian.)

Mádai, L. 1927: A Császárfürdő monográfiája (Monograph of the Császár Spa). - Budapest, 92 p. (In Hungarian.)

Mádl-Szőnyi, J., J. Tóth 2009: The Duna-Tisza Interfluve hydrogeological type section, Hungary. Hydrogeology Journal, 17, pp. 961-980.

Mádl-Szőnyi, J., J. Tóth, Sz. Simon, Gy. Pogácsás 2009: Soil and wetland salinization in the frame of the Duna-Tisza Interfluve hydrogeological type section. - Central European Geology, 51/3. pp. 203-217.

Müller, P. 1989: Hydrothermal paleokarst of Hungary. - In: Bosák, P. et al. (Eds): Paleokarst, A systematic and regional review, Amsterdam and Praha, Elsevier and Academia, pp. 155-163.

Nádor, A. 1994: Paleokarstic features in Triassic-Eocene carbonates: Multiple unconformities of a 200 million year karst evolution, Buda Mountain, Hungary. - Zentralblatt für Geologie und Paläontologie, Teil I., 1992, 11/12, pp. 1317-1329.

Nagymarosy, A., T. Báldi, M. Horváth 1986: The Eocene-Oligocene boundary in Hungary. - In: Pomerol, C. et al. (Eds): Terminal Eocene Events. Amsterdam, Elsevier, pp. 113-116. 
Papp, F. 1940: Budapest gyógyvizei (Mineral waters of Budapest). - Hidrológiai Közlöny (Bulletin of the Hungarian Hydrological Society), 20, pp. 68-80. (In Hungarian.)

Pogácsás, Gy., Gy. Juhász, J. Csizmeg, Á. Dudás, J. Mádl-Szőnyi, Sz. Simon, B. Czauner, N. Németh, A. Milankovich 2011: Late Miocene - Quaternary shortening and wrenching dominated groundwater flow in the central part of the Mid-Hungarian Mobile Belt. - Geophysical Research Abstracts Vol. 13, EGU2011-13414-2 2011 EGU General Assembly.

Sárváry, I. 1995: A budapesti termálkarszt kitermelhető vízkészleteinek felülvizsgálata (Re-evaluation of exploitable water resources of the Budapest thermal karst). - Hidrológiai Közlöny (Bulletin of the Hungarian Hydrological Society) 75, pp. 87-93. (In Hungarian.)

Schafarzik, F. 1928: Visszapillantás a budai hévforrások fejlődéstörténetére, (Retrospection on the evolution of the Buda Thermal Springs). - Hidrológiai Közlöny (Bulletin of the Hungarian Hydrological Society) 1, pp. 9-14. (In Hungarian.)

Schulhof, Ö. 1957: Magyarország ásvány és gyógyvizei (Mineral and spa waters of Hungary). Akadémiai Kiadó, Budapest, 963 p. (In Hungarian.)

Simon, Sz., J. Mádl-Szőnyi, I. Müller, Gy. Pogácsás 2011: Conceptual model for surface salinization in an overpressured and a superimposed gravity flow field, Lake Kelemenszék area, Hungary. Hidrogeology Journal, 19/3. 701. DOI 10.1007/s10040-011-0711-8

Tóth, J. 1962: A theory of groundwater motion in small drainage basins in central Alberta, Canada. J. Geophysical Research, 67(11), pp. 4375-4387.

Tóth, J. 1963: A theoretical analysis of groundwater flow in small drainage basins. - J. Geophysical Research 68, pp. 4795-4812.

Tóth, J. 1999: Groundwater as a geologic agent: an overview of the causes, processes, and manifestations. - Hydrogeology Journal, 7, pp. 1-14.

Vendel, M., P. Kisházi 1964: Összefüggések melegforrások és karsztvizek között a Dunántúliközéphegységben megfigyelt viszonyok alapján (Relationship of karst waters and hot springs in the Transdanubian Central Range). - MTA Múszaki Tudományok Osztályának Közleményei, 32, pp. 393-417. 